\title{
Impact of fish farms on maerl beds in strongly tidal areas
}

\author{
Jason Hall-Spencer ${ }^{1, *}$, Nicola White ${ }^{2}$, Ewan Gillespie ${ }^{3}$, Katie Gillham $^{4}$, Andy Foggo ${ }^{1}$ \\ ${ }^{1}$ Plymouth Marine Institute, University of Plymouth, Drake Circus, Plymouth PL4 8AA, UK \\ ${ }^{2}$ Haskoning UL Ltd, Elizabeth House, Emperor Way, Exeter EX1 3QS, UK \\ ${ }^{3}$ Scottish Environment Protection Agency, Dingwall IV7 9X8, UK \\ ${ }^{4}$ Scottish Natural Heritage, Westercraigs, Inverness IV3 8NW, UK
}

\begin{abstract}
In Scotland, Atlantic salmon Salmo salar cages are being moved out of areas with slow water movements, to disperse wastes and reduce impacts on benthic communities. This first study of the effects of fish farms on maerl beds (red algal coralline gravels of high conservation importance) demonstrated major impacts on the benthos, even in strongly tidal areas. SCUBA surveys of 3 fish farms located over maerl revealed a build-up of waste organic matter and 10 to 100 -fold higher abundances of scavenging fauna (e.g. Necora puber, Pagurus bernhardus) than on 6 reference maerl beds. Visible waste was noted up to $100 \mathrm{~m}$ from cage edges, and all 3 farms caused significant reductions in live maerl cover, upon which this habitat depends. Near-cage infaunal samples showed significant reductions in biodiversity, with small Crustacea (ostracods, isopods, tanaids and cumaceans) being particularly impoverished in the vicinity of cages, and significant increases in the abundance of species tolerant of organic enrichment (e.g. Capitella spp. complex, Ophryotrocha hartmanni). Relocation of fish farms to areas with strong currents is unlikely to prevent detrimental effects to the structure and organisation of the benthos, and 'fallowing' (whereby sites are left unstocked for a period of time to allow benthic recovery) is inadvisable where slow-growing biogenic habitats such as maerl are concerned, as this may expand the area impacted.
\end{abstract}

KEY WORDS: Salmon farming $\cdot$ Maerl $\cdot$ Organic enrichment $\cdot$ Benthos $\cdot$ Scotland

Resale or republication not permitted without written consent of the publisher

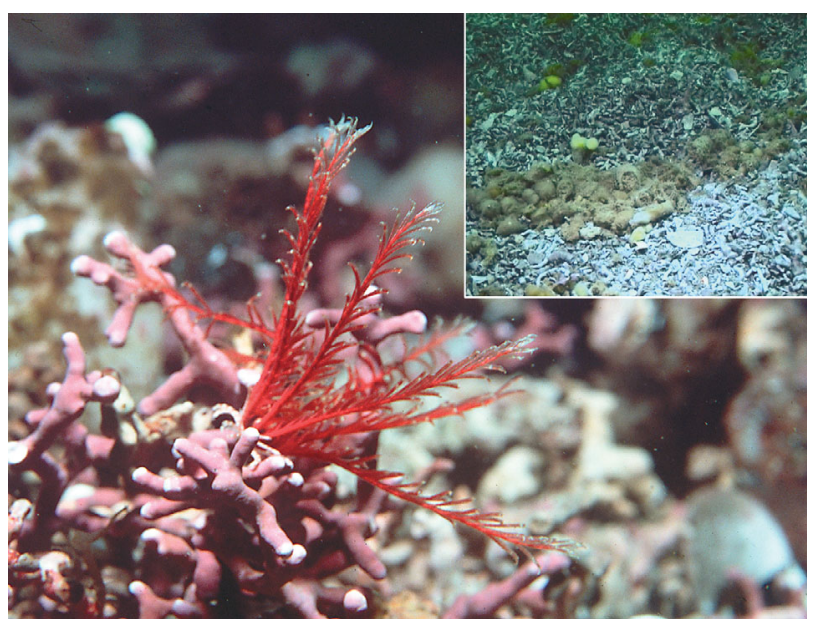

This first study on the effects of offshore salmon farms on strongly tidal maerl beds (above) reveals that strong currents do not prevent major degradation of benthic habitats (inset). Changes in management policy are therefore required to prevent detrimental effects to seabed ecology, and rotation of farmed sites (fallowing) is inadvisable where slow-growing biogenic habitats are concerned.

Photos: Jason Hall-Spencer

\section{INTRODUCTION}

Marine fish farming is the fastest growing food production sector in the world and its impacts require careful management to prevent unnecessary damage to coastal ecosystems (FAO 2002). As the industry expands and evolves, environmental regulatory agen- 
cies strive to modify and develop their strategies to encourage environmentally and socio-economically sustainable development. Scotland is now the largest aquaculture producer in the European Union, with products worth around £500 million (Sterling) per annum (RCEP 2004). As in Chile, British Columbia and Norway, Scotland's fjords provide the sheltered cool waters and high water exchange that are well suited for farming salmon. Almost all fjords in Scotland now have mariculture developments and the national production of Salmo salar L. increased from $5000 \mathrm{t} \mathrm{yr}^{-1}$ in the 1980s to $145000 \mathrm{t} \mathrm{yr}^{-1}$ in 2002. This has provided jobs and infrastructure in remote rural areas, but concerns have been raised over the environmental effects of such development (Fernandes et al. 2001, RCEP 2004).

This study concentrated on the effects of organic deposition on the benthos in locations with fast water movements. Such effects are well documented for fish farms situated in areas with slow water movements in muddy fjord habitats (Pearson \& Black 2001), and conform to the model of species succession in relation to organic enrichment proposed by Pearson \& Rosenberg (1978), but the effects of fish farms are poorly known in areas with fast currents (Lee et al. 2006). In sheltered conditions, around $5 \%$ of protein-rich salmon pellets (ca. $55 \%$ fishmeal) are uneaten and pass through fish cages, along with fish faeces. Some waste feed may be eaten by wild fish, but much of it builds up below cages in areas with low current speeds, resulting in alterations to infaunal community structure, such as increased abundance of opportunistic scavengers and lowered species diversity (Pearson \& Black 2001). Our study was initiated in light of a shift in management policy encouraging the movement of cages away from sites with low current speeds to areas with stronger currents in order to disperse wastes and, hopefully, lessen the potential impacts upon the seabed below and adjacent to cages (Fernandes et al. 2001, Henderson et al. 2001). Predictive deposition models used for licencing farm operations have been developed and validated for use on muddy substrata, but not in high energy sites (Henderson et al. 2001, Cromey et al. 2002), which support a different set of benthic biotopes.

In Scotland, highly dispersive sites can be suitable for maerl habitats which comprise loose-lying coralline red algae (Corallinales, Rhodophyta) that can build-up over millennia to create carbonate-rich gravel deposits that form isolated habitats of high benthic biodiversity (Hall-Spencer 1998, Grall \& Hall-Spencer 2003, Grall et al. 2006). Maerl growth requires light for photosynthesis and usually occurs in areas with clear water and strong currents. Laboratory experiments show that smothering by fine sediment and lowered oxygen concentrations are particularly damaging to maerlforming algae (Wilson et al. 2004). The conservation importance of maerl beds is increasingly recognised, not only because of their longevity and high biodiversity, but also due to potential benefits for commercial fisheries. Maerl beds can harbour high densities of broodstock bivalves and act as nursery areas for the juvenile stages of commercial species such as cod Gadus morhua L., crabs Cancer pagurus L. and scallops Aequipecten opercularis (L.), which are attracted to the complex 3-dimensional unconsolidated structure (Kamenos et al. 2004).

The movement of fish farming operations to more open conditions is relatively new, with few studies of their effects on benthic habitats in strong current regimes (Lee et al. 2006). The present study aimed to establish the effects of salmon farms upon maerl habitats, focusing on the impacts of organic deposition upon the associated epifaunal and infaunal communities. Salmon farms and reference sites were surveyed in 3 widely separated localities to determine if (1) strong currents prevented a build up of organic waste on the seabed, (2) farm waste had significant effects on live maerl cover and (3) farm waste had significant effects on benthic community structure.

\section{MATERIALS AND METHODS}

Scottish Environmental Protection Agency (SEPA) records showed that in 2003 there were 346 salmon farms operating in Scotland, of which 16 were situated above maerl beds. To obtain a wide geographic spread, we chose 3 farms that were 200 to $350 \mathrm{~km}$ apart and located over shallow sublittoral maerl beds in Shetland (North Sandwick, Yell; $60.640^{\circ} \mathrm{N}$, $0.990^{\circ} \mathrm{W} ;-14 \mathrm{~m}$ chart datum [CD]), Orkney (Puldrite Bay, Wide Firth; $59.045^{\circ} \mathrm{N}, 3.005^{\circ} \mathrm{W} ;-14 \mathrm{~m} \mathrm{CD}$ ) and South Uist (North Bay, Loch Sheilavaig; $57.346^{\circ} \mathrm{N}$, $7.237^{\circ} \mathrm{W}_{i}-10 \mathrm{~m} \mathrm{CD}$ ). Fish farming began at the Shetland farm in May 1991, the Orkney farm in 1993 and the South Uist farm in 1999. For each site, SEPA provided annual monitoring reports and hydrographic data sets. Diving surveys were carried out between 24 May and 29 June 2003 when these farms were permitted to stock $995 \mathrm{t}, 980 \mathrm{t}$ and $311 \mathrm{t}$ of salmon, respectively, with the highest feeding rate $(698 \mathrm{~kg}$ pellets pen $^{-1} \mathrm{~d}^{-1}$ ) at the Shetland farm. Circular plastic-ringed cages were in use in Shetland (where adult salmon were fed large pellets from a feed barge) and in Orkney (where smolts were hand fed with smaller feed pellets). In South Uist, adult salmon were held in rectangular metal cages and were fed large pellets from automatic hoppers fitted to each cage. At each farm, we laid out 4 weighted transect lines on the sea bed at 
right angles from cage edges to locate 4 sets of stations at 0,25 and $50 \mathrm{~m}$, and 2 sets of stations at 75 and $100 \mathrm{~m}$ from the cages. Near each farm, pairs of shallow sublittoral ( -10 to $-14 \mathrm{~m} \mathrm{CD})$ reference maerl beds were surveyed at sites 500 to $1000 \mathrm{~m}$ distant from any known anthropogenic sources of organic enrichment $\left(60.649^{\circ} \mathrm{N}, 0.983^{\circ} \mathrm{W}\right.$ and $60.649^{\circ} \mathrm{N}, 0.982^{\circ} \mathrm{W}$ in Shetland; $59.049^{\circ} \mathrm{N}, 2.993303^{\circ} \mathrm{W}$ and $59.047^{\circ} \mathrm{N}, 2.991^{\circ} \mathrm{W}$ in Orkney; $57.346^{\circ} \mathrm{N}, 7.24739^{\circ} \mathrm{W}$ and $57.346^{\circ} \mathrm{N}$, $7.247^{\circ} \mathrm{W}$ in South Uist). Station positions were recorded using GPS (Garmin E-trex).

Effects on the epibenthos. At 6 reference sites and at $25 \mathrm{~m}$ intervals along 4 perpendicular weighted transect lines, divers recorded surface conditions of the sea bed around each farm. Live and dead maerl cover was recorded in three $0.25 \mathrm{~m}^{2}$ quadrats (divided into $10 \times$ $10 \mathrm{~cm}$ squares) dropped haphazardly onto the seabed at each station, giving 6 to 12 replicate quadrats per sampling distance from each farm. At each sampling station, feed pellets, Beggiatoa mats (sulphur-reducing bacterial colonies indicative of anoxic sediment conditions) and fish farm litter (e.g. ropes, plastic mesh, old mooring gear) were noted and the abundances of conspicuous scavengers (e.g. crabs and whelks) were estimated using the semiquantitative 'SACFOR' scale, where $\mathrm{S}=$ Superabundant, $\mathrm{A}=$ Abundant, $\mathrm{C}=\mathrm{Com}$ mon, $\mathrm{F}=$ Frequent, $\mathrm{O}=$ Occasional and $\mathrm{R}=$ Rare (see Hiscock 1998 and Table 1 for details). Maerl samples were collected from quadrats at 0 and $50 \mathrm{~m}$ from the cages and at reference sites. These were examined microscopically (first using $\times 40$ dissection light microscopy, then $\times 2200$ scanning electron microscopy) to determine their identity and their condition (by examining their phycobilin pigmentation and the structure of the surface layer of cells). Taxonomic identification followed Irvine \& Chamberlain (1994) and was achieved using a JSM 5600 LV Scanning Electron Microscope.

Effects on the infauna. In Shetland and Orkney, divers took 5 samples from reference sites and 5 from each of the transect line sampling stations around

Table 1. Abundance of scavengers (ind. $\left.\mathrm{m}^{-2}\right)$ from in situ estimates $\left(\mathrm{C}=1-9 \mathrm{~m}^{-2}, \mathrm{~F}=\right.$ $0.1-0.9 \mathrm{~m}^{-2}, \mathrm{O}=0.01-0.09 \mathrm{~m}^{-2}, \mathrm{R}=0.001-0.009 \mathrm{~m}^{-2},-=$ not seen $)$. Ref = Reference

\begin{tabular}{|lcccccc|}
\hline Taxa & \multicolumn{2}{c}{$\begin{array}{c}\text { Shetland } \\
\text { Ref site }\end{array}$} & Near cage & \multicolumn{2}{c|}{ Orkney } & \multicolumn{2}{c|}{$\begin{array}{c}\text { South Uist } \\
\text { Ref site }\end{array}$} & Near cage & Ref site & Near cage \\
\hline Cancer pagurus & $\mathrm{O}$ & $\mathrm{F}^{\mathrm{a}}$ & $\mathrm{R}$ & $\mathrm{R}$ & $\mathrm{O}$ & $\mathrm{R}$ \\
Carcinus maenas & $\mathrm{R}$ & - & - & $\mathrm{O}^{\mathrm{a}}$ & $\mathrm{R}$ & $\mathrm{F}^{\mathrm{a}}$ \\
Liocarcinus spp. & $\mathrm{O}$ & $\mathrm{F}^{\mathrm{a}}$ & $\mathrm{O}$ & $\mathrm{F}^{\mathrm{a}}$ & $\mathrm{O}$ & $\mathrm{F}^{\mathrm{a}}$ \\
Necora puber & $\mathrm{R}$ & $\mathrm{O}^{\mathrm{a}}$ & $\mathrm{R}$ & $\mathrm{O}^{\mathrm{a}}$ & $\mathrm{R}$ & $\mathrm{O}^{\mathrm{a}}$ \\
Paguridae & $\mathrm{O}$ & $\mathrm{F}^{\mathrm{a}}$ & $\mathrm{O}$ & $\mathrm{F}^{\mathrm{a}}$ & $\mathrm{O}$ & $\mathrm{F}^{\mathrm{a}}$ \\
Asterias rubens & $\mathrm{R}$ & $\mathrm{R}$ & $\mathrm{R}$ & $\mathrm{O}^{\mathrm{a}}$ & $\mathrm{O}$ & $\mathrm{C}^{\mathrm{a}}$ \\
Buccinum undatum & $\mathrm{R}$ & $\mathrm{O}^{\mathrm{a}}$ & $\mathrm{O}$ & - & $\mathrm{R}$ & $\mathrm{O}^{\mathrm{a}}$ \\
a10 to 100 times higher abundance near cages & & & \\
\hline
\end{tabular}

cages, using cylindrical capped cores $\left(0.01 \mathrm{~m}^{2}\right)$ inserted to a sediment depth of $20 \mathrm{~cm}$. On surfacing, core samples were double bagged and preserved using 15 to $20 \%$ borax-buffered formalin for later laboratory sieving (1 mm mesh). The $1 \mathrm{~mm}$ fraction was elutriated with fresh water to float off lighter fauna. This elutriate was then examined using a dissecting microscope, for identifying and counting the species present. The heavy elements remaining were then scanned under low magnification and fauna removed, identified and counted.

Data analysis. Differences in live maerl cover and infaunal diversity of core samples (Shannon-Wiener $\mathrm{H}^{\prime}$ ) were tested using univariate analyses. Preliminary analysis using ANOVA indicated a strong interaction between farms and sampling distance from farms (using reference sites as a category). Therefore, to avoid inflating Type I errors by using multiple testing, and to account for the distance of the reference sites from the cages, a separate slopes General Linear Model (GLM) was adopted in Statistica 6.0 (www.statsoft.com) for both analyses. The Type III least squares hypothesis decomposition was used to account for the unbalanced nature of the designs. The distance of samples from cage edges was used as the covariate and sites as the main effect to analyse the slopes of the relationships with distance. Proportional live maerl cover data were subjected to arcsin transformation, and Bartlett's test for non-homogeneity of variances was applied prior to both GLMs. Neither data set required transformation to homogenise variances.

Multivariate analyses were carried out using PRIMER-E 5.0 (Clarke \& Warwick 2001) on 4th-root transformed abundance data for Shetland and Orkney core samples to produce a Bray-Curtis sample similarity matrix. Overall assemblage similarity between sample locations (pairs of reference sample sets for each site were considered to be in the same category) was compared using an a priori 2-way crossed analysis of similarity (ANOSIM). A second similarity matrix was then calculated for each site to analyse the overall percentage contribution of different taxa to the dissimilarity between samples taken near to $(0 \mathrm{~m}$ and $25 \mathrm{~m})$, and far from the cages (100 $\mathrm{m}$ and reference sites) across both sites using the similarity percentages (SIMPER) routine in PRIMER-E. Finally, ranked species abundance plots (K-dominance plots) were constructed for each site to analyse changes in assemblage structure (see Lambshead et al. 1983). 


\section{RESULTS}

Divers noted strong currents at all fish farms and all control sites. Current meter data from annual environmental monitoring reports showed peak near-seabed values of ca. $0.5 \mathrm{~m} \mathrm{~s}^{-1}$ for Shetland, $0.7 \mathrm{~m} \mathrm{~s}^{-1}$ for Orkney and $0.4 \mathrm{~m} \mathrm{~s}^{-1}$ for South Uist. Currents were consistently strongest at the Orkney fish farm, with regular periods of sluggish water-flow at all 3 farms. The most detailed hydrographic data were available for the Shetland farm, where current speeds recorded for a $15 \mathrm{~d}$ survey period had means of $0.11,0.12$ and $0.12 \mathrm{~m} \mathrm{~s}^{-1}$ and maxima of $0.21,0.21$ and $0.47 \mathrm{~m} \mathrm{~s}^{-1}$ for heights of $3.2 \mathrm{~m}$, $7.7 \mathrm{~m}$ and $10.7 \mathrm{~m}$ above the sea bed, respectively.

\section{Effects on the epibenthos}

There was consistently less live maerl around all 3 farms than the 50 to $60 \%$ cover that typified reference sites (Fig. 1), with a consistently significant response of maerl cover to distance from the cages $\left(\mathrm{R}^{2}\right.$ (adjusted) $=$ $\left.0.63 ; \mathrm{F}_{5}=37.43, \mathrm{p}<0.001\right)$. The Shetland farm had the highest cover of live maerl close to the cages; here the sea bed was sculpted into a series of megaripples indicating live maerl transportation into the area during rough weather (see Hall-Spencer \& Atkinson 1999). Maerl around the Orkney and South Uist fish



Fig. 1. Mean percentage $+\mathrm{SE}$ of live maerl in replicate 0.25 $\mathrm{m}^{2}$ quadrats taken at reference sites $(\mathrm{n}=6)$ and on perpendicular transects at $0 \mathrm{~m}(\mathrm{n}=12), 25 \mathrm{~m}(\mathrm{n}=12), 50 \mathrm{~m}(\mathrm{n}=12), 75 \mathrm{~m}$ $(\mathrm{n}=6)$ and $100 \mathrm{~m}(\mathrm{n}=6)$ from 3 salmon farms in May/June 2003. NB: hard substratum but no maerl was found at $100 \mathrm{~m}$ from the South Uist farm farms was not megarippled (indicating less mobility); most of it was dead and clogged with black sulphurous silt next to the cages, indicating anoxic conditions. Maerl thalli collected for identification were all Phymatolithon calcareum (Pallas) Adey et McKibbin; many specimens collected near cages had a mottled appearance, due to loss of pigmentation and erosion of the epithallus. Most (ca. 90\%) of the live maerl collected $50 \mathrm{~m}$ from the salmon cages, and all of the live maerl collected at the reference sites had a healthy, uniformly pigmented appearance and intact epithallial cells.

All reference sites (2 in Shetland, 2 in Orkney and 2 in South Uist) showed no signs of organic waste, with abundant epiphytic growths of foliose red algae, small sponges, hydroids and bryozoans. Large bivalve siphons, e.g. Tapes rhomboides (Pennant), Dosinia exoleta (L.), and tentacles of the holothurian Neopentadactyla mixta (Ostergren) indicated high infaunal biomass. Vagile fauna was abundant, particularly small gastropods, cryptic Crustacea (e.g. amphipods, squat lobsters, small crabs) and juvenile ophiuroids. At the fish farms, uneaten feed and fish faeces had accumulated in troughs between sediment waves, in pits dug by bioturbators (e.g. Cancer pagurus), and within the interlocking matrix of maerl thalli. Fig. 2 illustrates the 'footprints' of visible wastes derived from in situ observations at the 3 sites. Physical impacts included crushed maerl under mooring chains, shading and smothering by nets together with ropes and mussel shells (Mytilus edulis L.) on the sea bed that had fallen from the fish farms. Near-cage sites had few attached epiphytes and epifauna, no visible bivalve siphons, an absence of large suspension feeders (e.g. N. mixta) and a lowered diversity and abundance of cryptic fauna such as small crustaceans and gastropods. The South Uist site was the most visibly impacted, with Beggiatoa mats and decomposing crabs Carcinus maenas (L.) and Necora puber (L.), sea urchins Echinus esculentus L. and tunicates Ciona intestinalis (L.). Feed pellets were seen on the sea bed near all cages, to a distance of $100 \mathrm{~m}$ from the cages in Orkney, where currents were strongest and the smallest pellets were in use. Whelks, crabs and starfish were seen feeding on farm waste around each farm, and most of these taxa were over 10 times more abundant near farms than at reference sites (Table 1).

\section{Effects on the infauna}

Sponges and bryozoans were present in small numbers in core samples but were excluded from analyses due to the difficulties of enumerating colonial organisms. Species from a diverse range of other phyla were 

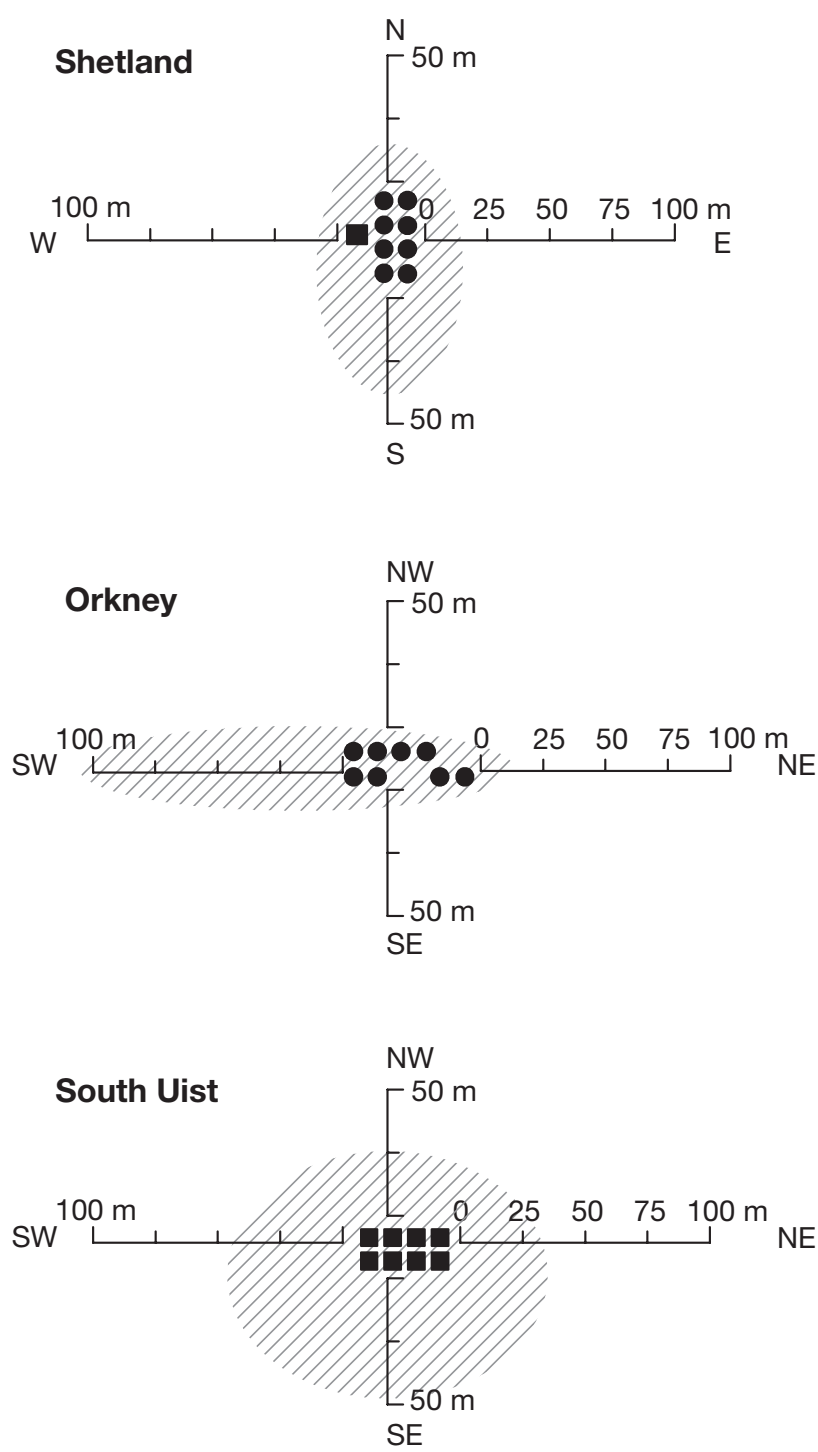

Fig. 2. Schematic diagram showing layout of 3 salmon farms surveyed, with shaded areas indicating visible organic enrichment (feed pellets, fish faeces and/or Beggiatoa mats) recorded by divers around salmon farms on maerl beds in May/June 2003

identified and counted (viz. Cnidaria, Nemertea, Priapulida, Chaetognatha, Sipuncula, Annelida, Chelicerata, Crustacea, Mollusca, Phoronida, Echinodermata, Chordata). Each of these phyla had a greater number of species in reference cores than in cores collected along fish farm transects. For example, the numbers of species for the 4 most diverse phyla collected in ten $0.01 \mathrm{~m}^{2}$ cores at reference sites versus numbers in ten $0.01 \mathrm{~m}^{2}$ cores from close to the cages were $72: 56$ for Annelida, 40:28 for Crustacea, 21:12 for Mollusca and 12:5 for Echinodermata. Macrofaunal diversity increased consistently with distance away from the cages $\left(\mathrm{R}^{2}\right.$ (adjusted) $\left.=0.31, F_{3}=21.88, \mathrm{p}<0.001\right)$. Diversity
$\left(H^{\prime}\right)$ averaged $4.59 \pm 0.39$ at reference sites, $3.87 \pm 0.79$ at $100 \mathrm{~m}$ from the cages, $3.83 \pm 0.75$ at $75 \mathrm{~m}, 3.6 \pm 0.95$ at $50 \mathrm{~m}, 3.31 \pm 0.99$ at $25 \mathrm{~m}$ and $2.31 \pm 1.07$ at $0 \mathrm{~m}$.

There was a clear, consistent effect of distance from the cages on the assemblages at each site (ANOSIM $\mathrm{R}$ $=0.598, p<0.001)$. A gradient of assemblage difference between pairs of samples according to distance from the cages was evident (Tables $2 \& 3$ ), with consistent differences between reference sites and those nearer to the cages. SIMPER analysis showed that a few opportunistic species, e.g. the polychaetes Capitella spp. complex and Ophryotrocha hartmanni Claparède et Mecznikow, were rare at reference sites but were significantly more abundant close to cages (Fig. 3). Conversely, many maerl-dwelling taxa that were abundant at reference sites had marked reductions in population density close to the farm cages. Fig. 4 shows the reduction in ostracods and cumaceans near to farm cage sites. The following isopods, tanaids and cumaceans were plentiful at reference sites, but were clearly impoverished at farm cage sites: Gnathidae sp. indet., Eurydice juvenile sp. indet., Cymodoce sp., Janira maculosa Leach, Microcharon harrisi Spooner, Munna sp., Paramunna bilobata G.O. Sars, Eurycope sp., Idotea granulose Rathke, Leptognathia breviremis Liljeborg, L. paramanca Lang, Pseudoparatanais batei G.O. Sars, Tanaopsis graciloides Liljeborg, Typhlotanais microcheles G.O. Sars, Vaunthompsonia cristata Bate, Cumella pygmaea G.O. Sars, Nannastacus brevicaudatus Calman, N. unguiculatus Bate.

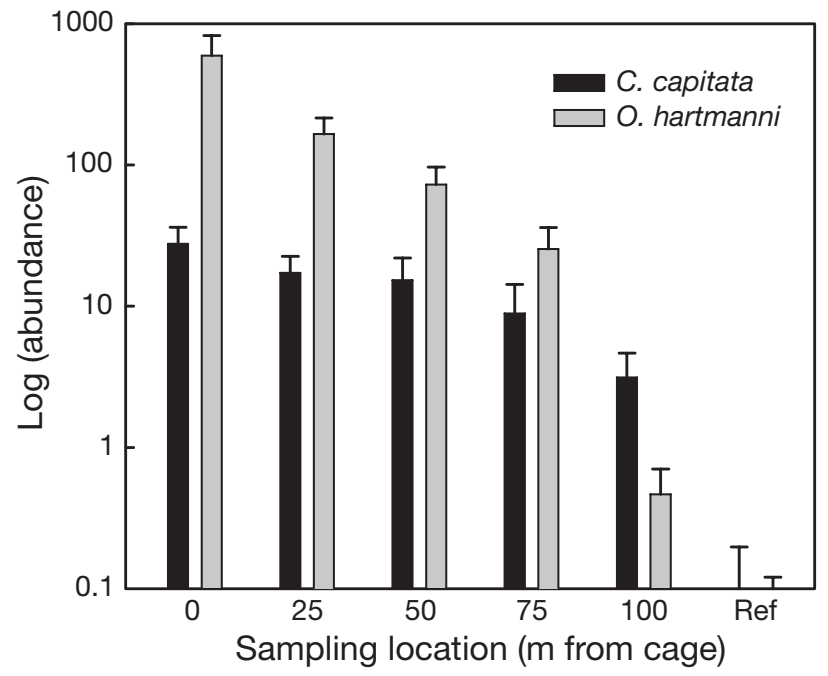

Fig. 3. Capitella spp. complex and Ophryotrocha hartmanni. Mean number + SE recorded in replicate $0.01 \mathrm{~m}^{2}$ core samples taken on reference maerl beds and on transects at 0 to $100 \mathrm{~m}$ from salmon cages in Shetland and Orkney, Scotland, June 2003 ( $\mathrm{n}=40$ at 0,25 and $50 \mathrm{~m} ; \mathrm{n}=20$ at 75 and $100 \mathrm{~m}$ and reference sites). NB: log scale and very high abundances near cages 
Table 2. SIMPER analysis comparing infaunal assemblages near cages ( 0 and $25 \mathrm{~m})$ with distant sites (100 $\mathrm{m}$ and reference sites); data for Shetland and Orkney combined. NB: arbitrary cutoff at $30 \%$ cumulative dissimilarity; average Bray-Curtis dissimilarity between samples in the 2 groups $=7859$

\begin{tabular}{|c|c|c|c|c|c|}
\hline \multirow{2}{*}{ Species } & \multirow{2}{*}{ Phylum } & \multirow[b]{2}{*}{$\begin{array}{c}\text { Increasing/decreasing } \\
\text { near cage }\end{array}$} & \multirow{2}{*}{$\begin{array}{l}\text { Mean abundance } \\
\text { Near } \\
\text { cage }\end{array}$} & \multirow{2}{*}{$\begin{array}{l}\text { Far from } \\
\text { cage }\end{array}$} & \multirow[b]{2}{*}{$\begin{array}{l}\text { Cumulative } \\
\% \text { dissimilarity }\end{array}$} \\
\hline & & & & & \\
\hline Ophryotrocha hartmanni & Annelida & + & 281.93 & 0.23 & 2.75 \\
\hline Socarnes erythrophthalmus & Crustacea & + & 47.02 & 30.23 & 4.58 \\
\hline Capitella spp. complex & Annelida & + & 20.05 & 1.40 & 6.24 \\
\hline Chone filicaudata & Annelida & - & 24.33 & 45.31 & 7.76 \\
\hline Phyllodoce mucosa & Annelida & + & 18.69 & 1.23 & 9.26 \\
\hline Amphipholis squamata & Echinodermata & - & 5.44 & 18.77 & 10.74 \\
\hline Enchytraeidae sp.1 & Annelida & - & 6.71 & 19.37 & 12.20 \\
\hline Ostracoda spp. & Crustacea & - & 5.85 & 19.40 & 13.63 \\
\hline Ceradocus semiserratus & Crustacea & - & 9.47 & 13.2 & 15.02 \\
\hline Parametaphoxus fultoni & Crustacea & - & 3.80 & 14.86 & 16.35 \\
\hline Leptocheirus pectinatus & Crustacea & - & 3.24 & 42.63 & 17.56 \\
\hline Urothoe elegans & Crustacea & - & 2.69 & 4.80 & 18.69 \\
\hline Mediomastus fragilis & Annelida & - & 2.27 & 3.31 & 19.82 \\
\hline Tubificidae sp.1 & Annelida & + & 3.47 & 2.06 & 20.95 \\
\hline Exogone hebes & Annelida & + & 3.29 & 1.97 & 22.05 \\
\hline Tubificidae sp.2 & Annelida & - & 1.87 & 3.03 & 23.10 \\
\hline Gyptis propinqua & Annelida & - & 1.13 & 3.80 & 24.06 \\
\hline Cumella pygmaea & Crustacea & - & 0.69 & 4.23 & 25.00 \\
\hline Ophiothrix fragilis & Echinodermata & - & 0.38 & 6.91 & 25.93 \\
\hline Paramunna bilobata & Crustacea & - & 1.56 & 3.94 & 26.86 \\
\hline Prionospio banyulensis & Annelida & - & 0.75 & 2.26 & 27.76 \\
\hline Liljeborgia kinahani & Crustacea & - & 0.56 & 2.94 & 28.62 \\
\hline Spaerosyllis taylori & Annelida & - & 1.02 & 3.51 & 29.48 \\
\hline Nannastacus unguiculatus & Crustacea & - & 0.13 & 4.63 & 30.32 \\
\hline
\end{tabular}

These dramatic community changes are illustrated by $K$-dominance curves for infaunal data from Shetland and Orkney combined (Fig. 5). Samples closest to the cages were dominated by very high numbers of 1 or 2 species and were less diverse. With increasing distance from the cages, the assemblages became less dominated by a few species and more similar to reference sites, where large numbers of species occurred at low densities.

Table 3. Significance levels of differences in pairwise combinations of distances using 2-way crossed ANOSIM for infaunal data from Shetland and Orkney combined. ${ }^{* * *} \mathrm{p}<0.001$, ${ }^{* *} p<0.01,{ }^{*} p<0.05$, ns not significantly different

\begin{tabular}{|lccccc|}
\hline & \multicolumn{5}{c|}{ Distance from cages (m) } \\
& 0 & 25 & 50 & 75 & 100 \\
\hline 25 & $\mathrm{~ns}$ & & & & \\
50 & $\mathrm{~ns}$ & $\mathrm{~ns}$ & & & \\
75 & ${ }^{* * *}$ & ${ }^{*}$ & $\mathrm{~ns}$ & & \\
100 & ${ }^{* * *}$ & ${ }^{* * *}$ & ${ }^{* *}$ & $*$ & \\
Reference & ${ }^{* * *}$ & ${ }^{* * *}$ & ${ }^{* * *}$ & ${ }^{* * *}$ & $* * *$ \\
& & & & & \\
\hline
\end{tabular}

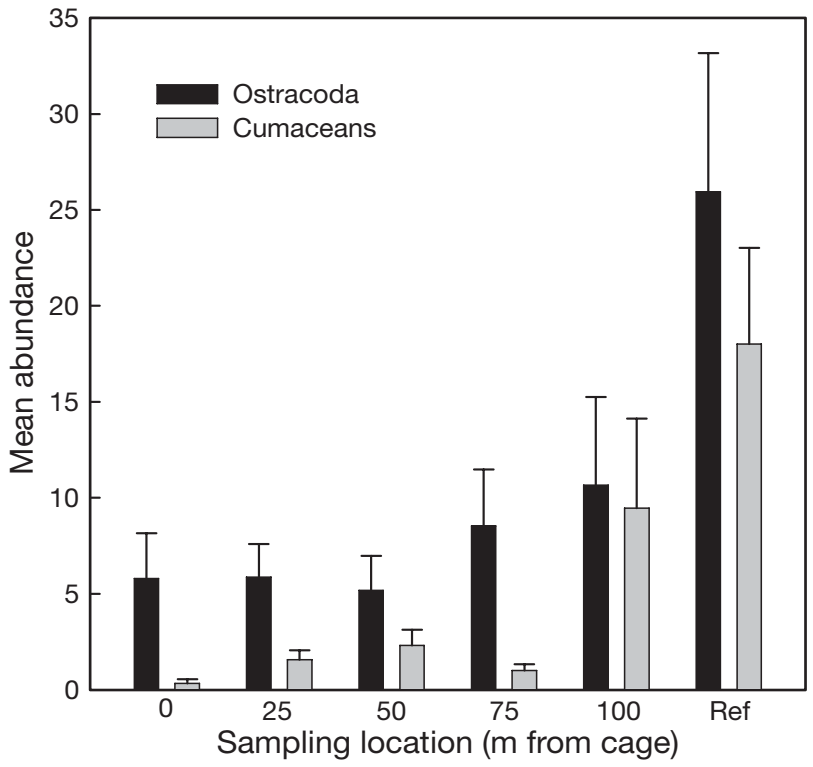

Fig. 4. Mean number + SE of ostracods and cumaceans found in $0.01 \mathrm{~m}^{2}$ core samples taken on reference maerl beds and on transects at 0 to $100 \mathrm{~m}$ from salmon cages in Shetland and Orkney, Scotland, June 2003 ( $\mathrm{n}=40$ at 0,25 and $50 \mathrm{~m} ; \mathrm{n}=20$ at 75 and $100 \mathrm{~m}$ and reference sites). Note their paucity near cages. Ref $=$ reference 


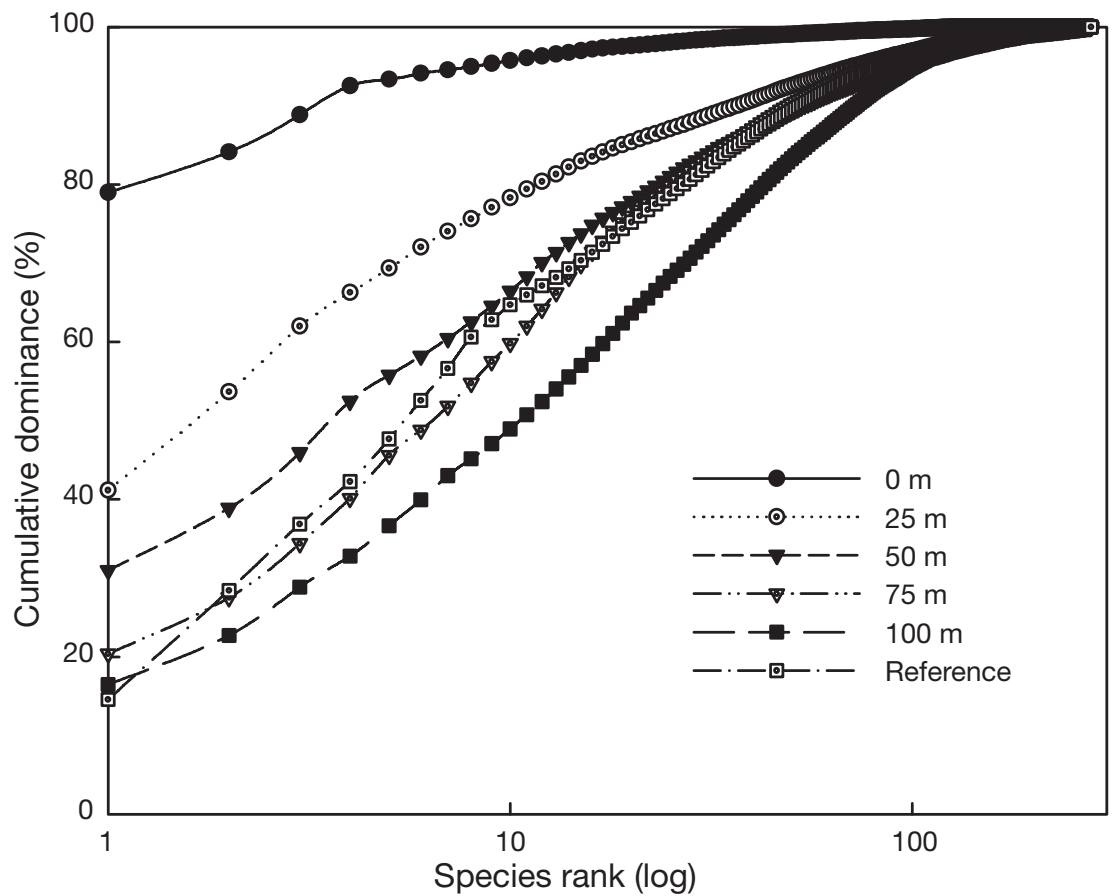

Fig. 5. K-dominance curves showing changes in community structure with distance from salmon farms in Shetland and Orkney, Scotland; data from $1 \mathrm{~mm}$ sieved $0.01 \mathrm{~m}^{2}$ core samples taken at reference sites and along transects around farm cages in June $2003\left(\mathrm{n}=80\right.$ at 0,25 and $50 \mathrm{~m}_{i} \mathrm{n}=40$ at 75 and $100 \mathrm{~m}$ and reference sites)

\section{DISCUSSION}

The need for this study arose from the increasing numbers of sea cage fish farms located over strongly tidal maerl beds, a habitat for which no previous environmental impact assessments had been made. The work involved close collaboration between industry, regulatory authorities and independent scientific advisors, following best practice recommendations given by Fernandes et al. (2001). The initial expectation, based on current measurements, was that even at high feeding rates (up to $698 \mathrm{~kg} \mathrm{pen}^{-1} \mathrm{day}^{-1}$ ) most of the particulate wastes from the fish farms would be dispersed and that there would be minimal effects on the benthos. In situ observations revealed that during periods of slow water flow, fish farm particulates settled in seabed depressions and became trapped within a complex interlocking matrix of maerl thalli, rather than being resuspended and dispersed widely as can occur on smooth sediments (Cromey et al. 2002). Surveys of 3 maerl beds over a wide geographic area $(500 \mathrm{~km})$ clearly demonstrated that, despite the action of strong currents, salmon farms could lead to a build-up of organic wastes in the vicinity of cages and significantly alter seabed benthos. The farmed sites, which had been in use for 4 to $12 \mathrm{yr}$, had each caused long-term environmental damage, because slow-growing photo- synthetic maerl thalli had been killed, inhibiting regeneration and growth of the habitat. These findings have important implications for the sustainable management of marine fish farming operations worldwide, as advances in sea-cage technology allow the positioning of cages at more exposed locations. Management procedures have been based largely on studies of fish farms located in sheltered conditions with open-ocean mariculture operations being considered advantageous, because they use locations in which enrichment effects can be mitigated by increased current activity and dilution (Henderson et al. 2001). Our study adds to that of Lee et al. (2006) in showing significant eutrophic effects in high energy habitats despite dilution due to exposed conditions.

The European Council Directive 92/43 (1992) provides legislative protection to maerl, which is now a key habitat within a number of UK Special Areas of Conservation and subject to a UK Habitat Action Plan that aims to maintain the extent, variety and quality of maerl beds and associated seaweed and animal communities (Wilson et al. 2004). The Nature Conservation (Scotland) Act (Anonymous 2004) places an onus upon environmental managers to conserve and promote biodiversity. Habitats such as maerl should therefore be taken into account in the development of regulation for fish farm authorisations. Phymatolithon calcareum was present at all 9 of the strongly tidal sites we surveyed and is the most widely distributed maerlforming species in the British Isles (Irvine \& Chamberlain, 1994). The fjordic coastline of North and West Scotland is well suited to maerl growth, with 376 records, compared with a combined total of around 16 sites in England and Wales combined (National Biodiversity Network, www.searchnbn.net). That maerl was predominantly dead or in poor condition close to cages, but increased in live cover with distance from the farms, is analogous to the detrimental effects of fish farms on slow-growing seagrass meadows (Dimech et al. 2002) and ties in with laboratory evidence showing that maerl is particularly sensitive to siltation and lowered oxygen tension (Wilson et al. 2004). This is particularly problematic since maerl grows only ca. $1 \mathrm{~mm}$ $\mathrm{yr}^{-1}$, forming seabed deposits that take 1000s of years to accumulate (Grall \& Hall-Spencer 2003). Thus whilst the practice of periodic abandonment of cage sites to allow recovery (fallowing) has been recommended as a 
management tool for sustainable fish farming (Fernandes et al. 2001), this remains controversial due to long recovery times (Pereira et al. 2004) and is not advantageous where slow-growing biogenic habitats are concerned. At sites where maerl beds have already been inadvertently degraded by fish farming operations, it makes environmental sense not to move farm location and impact areas elsewhere, as maerl recovery rates are so slow.

Our 6 strongly tidal reference sites had no visible signs of organic pollution and were highly biodiverse. The polychaete and crustacean components of the fauna were particularly rich, similar to those reported in French maerl deposits (Grall et al. 2006). In contrast, the 3 fish farm sites all had visible signs of organic enrichment (feed pellets, fish faeces and/or Beggiatoa mats) and significantly lower biodiversity. Similar reductions in the diversity of maerl beds have been linked to anthropogenic eutrophication and organic enrichment in the Bay of Brest (Grall \& Glémarec 1997). Shifts in trophic status and community structure are typical effects of organic enrichment in marine sediments (Pearson \& Rosenberg 1978), and were noted at all 3 fish farm sites, with most scavenging macrofauna (e.g. whelks and starfish) being 10 to 100 times as abundant close to the cages than at reference sites. Core sampling showed that some species were super-abundant in sediment collected near to the cages, e.g. the organic disturbance indicators Capitella spp. complex, the hypoxia- and sulphur-resistant Tubificoides benedini and the opportunistic scavenger Ophryotrocha hartmanni.

Donnan \& Moore (2003) recommended a moratorium, based on the precautionary principle, on fish farm licences above unexploited maerl beds, as maerl was thought to be easily damaged by fine particulate matter. The laboratory studies of Wilson et al. (2004) coupled with the present field study confirm that maerl habitats are highly susceptible to the effects of fish farm deposition, with significant effects recorded to at least $100 \mathrm{~m}$ from 3 farmed sites. This knowledge can now be incorporated into management procedures for sustainable fish farm development and has planning implications for other strongly tide-swept habitat types. The fallowing system whereby cage positions are rotated to allow the deposit-feeders of muddy fjord habitats time to process organic waste (Fernandes et al. 2001) is not suited to maerl habitats because of the likely longevity of the damage caused. High organic loading results in the long-term loss of living maerl, upon which generation of the habitat depends, and many species at shallow high-energy sites (e.g. maerl, sponges, hydroids, soft corals and bryozoans) are intolerant of smothering by organic particulates. The findings outlined here are likely to apply to sea cage fish farms in other fjordic settings, such as those in Chile, Canada, Tasmania and Norway where sensitive seabed habitats occur in strongly tidal areas. In the light of this study it would seem advantageous to limit potential environmental degradation (1) by careful consideration of alternatives to locating new fish farms on long-lived biogenic habitats, perhaps choosing less structurally complex sedimentary habitats in preference, and (2) if maerl habitats are to be licenced for salmon farming, then cage positions should be fixed within leased areas, as opposed to the fallowing system of site rotation which may extend damage to vulnerable habitats.

Acknowledgements. We are grateful to C. Howson, T. Mercer and A. Shaw for planning and execution of SCUBA fieldwork and to P. Garwood for infaunal identifications. J.H.S. had a Royal Society University Research Fellowship and the project was funded by Scottish Natural Heritage, the Scottish Environmental Protection Agency, Marine Harvest (Scotland) Ltd. and the Esmée Fairbairn Foundation.

\section{LITERATURE CITED}

Anonymous (2004) Nature Conservation (Scotland) Act. The Stationery Office Ltd, Edinburgh

Clarke KR, Warwick, RM (2001) Change in marine communities: an approach to statistical analysis and interpretation. PRIMER-E, Plymouth

Cromey CJ, Nickell TD, Black KD, Provost PG, Griffiths CR (2002) Validation of a fish farm waste resuspension model by use of a particulate tracer discharged from a point source in a coastal environment. Estuaries 25: 916-929

Dimech M, Borg JA, Schembri PJ (2002) Changes in the structure of a Posidonia oceanica meadow and in the diversity of associated decapod, mollusk and echinoderm assemblages, resulting from inputs of waste from a marine fish farm (Malta, Central Mediterranean). Bull Mar Sci 71: 1309-1321

Donnan DW, Moore PG (2003) International workshop on the conservation and management of maerl. Aquat Conserv Mar Freshw Ecosys 13:1-78

FAO (2002) The state of world fisheries and aquaculture. Food and Agriculture Organization, Rome

European Council Directive 92/43 (1992) Conservation of natural habitats and of wild flora and fauna. Official J Eur Commun L206:7-49

Fernandes TF, Eleftheriou A, Ackefors H, Eleftheriou M and 7 others (2001) The scientific principles underlying the monitoring of the environmental impacts of aquaculture. J Appl Ichthyol 17:181-193

Grall J, Glémarec M (1997) Using biotic indices to estimate macrobenthic community perturbations in the Bay of Brest. Estuar Coast Shelf Sci 44:43-53

Grall J, Hall-Spencer JM (2003) Problems facing maerl conservation in Brittany. Aquat Conserv Mar Freshw Ecosys 13:55-64

Grall J, Le Loc'h F, Guyonnet B, Riera P (2006) Community structure and food web based on stable isotopes $(\delta 15 \mathrm{~N}$ and $\delta 13 \mathrm{C}$ ) analyses of a North Eastern Atlantic maerl bed. J Exp Mar Biol Ecol 338:1-15 
Hall-Spencer JM (1998) Conservation issues concerning the molluscan fauna of maerl beds. J Conchol Spec Publ 2: 271-286

Hall-Spencer JM, Atkinson, RJA (1999) Upogebia deltaura (Crustacea, Thallassinidea) in Clyde Sea maerl beds, Scotland. J Mar Biol Assoc UK 79:871-880

Henderson A, Gamito S, Karakassis I, Pederson P, Smaal A (2001) Use of hydrodynamic and benthic models for managing environmental impacts of marine aquaculture. J Appl Ichthyol 17:163-172

Hiscock K (1998) Biological monitoring of marine Special Areas of Conservation: a handbook of methods for detecting change. Joint Nature Conservation Committee, Peterborough

Irvine LM, Chamberlain YMC (1994) Seaweeds of the British Isles, Vol 1, Part 2B. British Museum (Natural History), London

Kamenos NA, Moore PG, Hall-Spencer JM (2004) Small-scale distribution of juvenile gadoids in shallow inshore waters; what role does maerl play? ICES J Mar Sci 61:422-429

Lambshead PJD, Platt HM, Shaw KM (1983) The detection of differences among assemblages of marine benthic species

Editorial responsibility: Otto Kinne (Editor-in-Chief), Oldendorf/Luhe, Germany based on an assessment of dominance and diversity. J Nat Hist 17:859-874

Lee HW, Bailey-Brock JH, McGurr MM (2006) Temporal changes in the polychaete infaunal community surrounding a Hawaiian mariculture operation. Mar Ecol Prog Ser 307:175-185

Pearson TH, Black KD (2001) The environmental impact of marine fish cage culture. In: Black KD (ed) Environmental impacts of aquaculture. Academic Press, Sheffield, p 1-31

Pearson TH, Rosenberg R (1978) Macrobenthic succession in relation to organic enrichment and pollution in the marine environment. Oceanogr Mar Biol Annu Rev 16:229-311

Pereira PMF, Black KD, McLusky DS, Nickell TD (2004) Recovery of sediments after cessation of marine fish farm production. Aquaculture 235:315-330

RCEP (2004) Turning the tide: addressing the impact of fisheries on the marine environment. Royal Commission on Environmental Pollution, London

Wilson S, Blake C, Berges JA, Maggs CA (2004) Environmental tolerances of free-living coralline algae (maerl): implications for European maerl conservation. Biol Conserv 120:283-293

Submitted: July 28, 2006; Accepted: October 4, 2006 Proofs received from author(s): November 2, 2006 